\title{
Hearing Loss in $\alpha$-Thalassemia: A Case Report
}

\author{
Rawish Kumar ${ }^{1}$, Sanjay K Munjal ${ }^{1 *}$, Reena Das ${ }^{3}$ and Naresh K Panda ${ }^{4}$ \\ ${ }^{1}$ Speech \& Hearing Unit, Department of Otolaryngology, PGIMER, India \\ ${ }^{2}$ Department of Hematology, PGIMER, India \\ ${ }^{3}$ Department of Otolaryngology, PGIMER, India
}

Submission: April 07, 2017; Published: April 17, 2017

*Corresponding author: Sanjay K Munjal, Associate Professor \& In charge Speech and Hearing Unit, Department of Otolaryngology, PGIMER, Chandigarh, India, Tel: 9815653262; Email: sanjaymunjal1@hotmail.com

\section{Abstract}

Alpha-thalassemia is a hereditary disorder which generally occurs due to one or more deletions of the alpha-globin chain loci. There is a wide spectrum of phenotypic presentations, from clinically asymptomatic to mild to severe anemia. Hearing loss is prevalent in major thalassemia but has not been reported in carrier alpha thalassemia. Here we present a case with alpha-thalassemia with deletion of homozygous traits that had bilateral sensorineural hearing loss which might have developed due to defect in the production of oxygen-carrying pigments. It is hypothesized that the poor oxygen carrying capacity of the blood supply in the cochlea may be possible cause of hearing loss. Here it can be emphasized that cases with thalassemia should be screened for hearing loss so that it can be identified and managed at early stage.

Keywords: Thalassemia; Hearing loss; Audiometry

\section{Introduction}

Thalassemia is a hereditary disorder which is described as reduction in the synthesis of normal globin chain. In Indian subcontinent, thalassemia is a common genetic disorder. The thalassemia is classified as either alpha or beta depending on the affected chain. Alpha-thalassemia is not as severe in form as beta thalassemia. The reported prevalence is as a carrier in $90 \%$ of alpha thalassemia in India [1-6]. Healthy individuals have 4 alpha-globin genes, 2 on each chromosome 16. Alpha thalassemia syndromes are caused by deficient expression of 1 or more of the 4 alpha-globin genes on chromosome 16 and are characterized by absent or reduced synthesis of alpha-globin chains. Alpha thalassemia has been classified in four categories according to whether the loss of alpha-globin genes is complete or partial.

These are as follows:

a) Alpha(0) thalassemia: the functional deletion of both pairs of alpha-globin genes (--/-) have been identified and the condition of disorder results in hydrops fetalis, alpha thalassemia major, or hemoglobin Bart's in which fetuses die shortly after birth or in utero only due to severe anemia.

b) Silent carrier: Persons who inherit 3 normal alpha-globin genes $(-\alpha / \alpha \alpha)$ and the affected individual have no significant clinical symptoms. c) Alpha thalassemia trait: there are 2 normal alpha- globin chain through either heterozygosity $(\alpha \alpha /--)$ or homozygosity $(-\alpha /-\alpha)$, also referred to as alpha thalassemia minor and the affected individuals are clinically normal but frequently have minimal anemia and reduced Mean Corpuscular Volume (MCV) and Mean Corpuscular Hemoglobin (MCH).

d) Hemoglobin $\mathrm{H}$ disease ( $\mathrm{HbH}$ disease): only 1 alpha-globin chain $(-\alpha /--)$ is inherited and 3 are lost and affected individuals may have moderate anemia, folic acid deficiency and hepatosplenomegaly and jaundice [7]. The hearing loss has not been reported in carrier alpha thalassaemia but in major thalasaemia it is prevelant. The high frequency sensorineural hearing loss can also be observed with greater percentage of patients during intensive desferrioxamine therapy for thalassemia [2-4].

\section{Case Report}

A 23-years-old male patient reported with complaint of hard of hearing since last 10-15 years and it was gradually progressive. The pedigree analysis of family was done and is shown in Figure 1. The patient was second child of the family and first child was a girl who died within ten days after birth due to hydrops fetalis. There was no history of any significant medical illness as well as any external or middle ear pathology. The hearing evaluation was conducted in double walled acoustically treated room which conform to the ANSI/ISO standards for the maximum 
permissible noise levels using ORBITER 922 Clinical audiometer, MAICO MI34 tympanometer and Intelligent Hearing System (IHS2125) audiological equipments. Puretone audiometry revealed bilateral moderately-severe sensorineural hearing loss with flat audiogram configuration. The speech discrimination score (SDS) was performed at $40 \mathrm{~dB}$ above speech recognition threshold (SRT) and it was $92 \%$ in both ears.

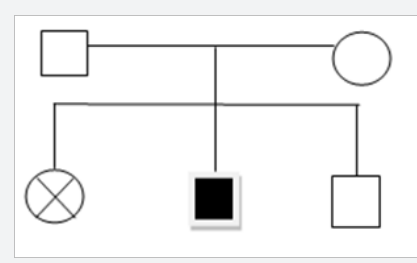

Figure 1: Description: Pedigree analysis of family.

The case had type-A tympanogram depicting no external or middle ear pathology. Bilateral transient evoked otoacoustic emissions (TEOAEs) and distortion product otoacoustic emissions (DPOAEs) were absent which indicated abnormal or damaged cochlea. The auditory brainstem evoked response audiometry was conducted on Neuro-audio instrument at 90 $\mathrm{dBnHL}$ at 19.3 stimulus rate with insert earphone ER-3A in both ears to rule out retrocochlear pathology. Absolute latency of peak $\mathrm{V}$ and interpeak latencies I-III, III-V and I-V were within normal limits indicating absence of retrocochlear pathology. Further, because hearing loss was progressive, patient underwent MRI radiological evaluation of cerebello-pontine (CP) angle. MRI investigation revealed no mass lesion at the $\mathrm{CP}$ angle and in the internal auditory meatus.

Medical Laboratory Investigation: Thalassemia and Hemoglobinopathy investigated in the department of Hematology suggested a possibility of $\alpha$-thalassemia trait. Through multiple polymer chain reactions (PCR), the DNA analysis for alpha genotyping suggested the deletion of $-\alpha^{3.7}$ homozygous trait. Further, parents were also undertaken for genetic evaluation and both of them were found to be carrier for alpha-thalassemia traits. This deletion of homogygous traits leads to reduction in mean corpuscles/cell volume (MCV), mean cell haemoglobin $(\mathrm{MCH})$ and $\mathrm{HbA}_{2}$. If there is a condition of deletion $-\alpha^{3.7}$ homozygous traits, it can lead to $\mathrm{Hb} \mathrm{H}$ inclusions.

\section{Discussion}

The alpha thalassemia is a recessive traits genetic condition where there is a defect in the production of oxygen-carrying pigments (haemoglobin) of red blood cells. The defect in alphaglobin expression in $\mathrm{HbH}$ patients $(-\alpha /-\alpha$ or $--/ \alpha \alpha)$ appears to have greater effects on terminal erythroid differentiation and red cell metabolism [7]. The deficiency of alpha chains leads to the formation of beta-chain tetramers $(\mathrm{HbH})$ and also deficiency in the formation of HbA2 in adults. The anemia that happens afterward is also due to shortened red blood cell survival where beta-chain tetramers $(\mathrm{HbH})$ can precipitate and form inclusion bodies which damage the red blood cell membrane. It does not readily form the inclusion bodies because $\mathrm{HbH}(\beta 4)$ is less stable than $\mathrm{Hb}$ Barts $(\gamma 4)$. However at the same time, no heme-heme intraction of both $\mathrm{Hb}$ Barts and beta chain tetramers is seen and which have high oxygen affinities and these consequently result in poor oxygen carrying.

The poor carrying capacity of oxygen of the blood supplied in the cochlear region can cause hearing loss [5]. The extramedullary erythropoiesis starts in the bone, liver, and spleen which are due to expansion of dyserythropoietic marrow in response to oxygen deprivation. This erythropoiesis gives rise to skeletal and bony deformities. The bony deformities and the poor oxygen carrying to the sensory structure may be the reason of hearing loss.

\section{Conclusion}

The reported case is a rare finding where a progressive hearing loss has been observed in case of alpha thalassemia with deletion of homozygous traits. Cases with alpha thalassemia should be screened for hearing loss so that it can be identified and managed at early stage.

\section{References}

1. Rudra T, Chakrabarti S, Sengupta B (2008) Alpha Thalassemia: Experience of Referral Cases in Kolkata, India. Int J Hum Genet 8(4): 357-360.

2. Galanello R (2004) Thalassemias and Related Disorders. In: Wintrobe's Clinical Hematology. ( $2^{\text {nd }}$ edn.), Lippincott William \& Wilkins, Baltimore, USA, pp: 1319-1365.

3. Weatherall DJ (2001) The Thalassemias In: Williams Hematology. (6 $6^{\text {th }}$ edn.), Mc Grow Hill, Philadelphia, USA, pp: 561-573.

4. Styles LA, Vichinsky EP (1996) Ototoxicity in hemoglobinopathy patients chelated with desferrioxamine. J Pediatr Hematol Oncol 18(1): 42-45.

5. Weatherall DG, Clegg JB (2000) The Thalassemia Syndromes. ( $4^{\text {th }}$ edn.), Oxford, Blackwell, UK

6. Galanello R, Cao A (2011) Alpha Thalasseimia. Genet Med 13(2): 8388.

7. Fucharoen S, Viprakasit V (2009) HbH disease: Clinical course and disease modifiers. Hematology Am Soc Hematol Educ Program 26-34. 
(C) This work is licensed under Creative BY DOI: $10.19080 /$ GJ0.2017.06.555696

\section{Your next submission with Juniper Publishers} will reach you the below assets

- Quality Editorial service

- Swift Peer Review

- Reprints availability

- E-prints Service

- Manuscript Podcast for convenient understanding

- Global attainment for your research

- Manuscript accessibility in different formats ( Pdf, E-pub, Full Text, Audio)

- Unceasing customer service

Track the below URL for one-step submission https://juniperpublishers.com/online-submission.php 